\title{
AZ MTA REGIONÁLIS TUDOMÁNYOS BIZOTTSÁG IRÁNYELVEI AZ AKADÉMIAI DOKTORI CÍM HABITUS VIZSGÁLATÁNÁL A TUDOMÁNYOS TELJESÍTMÉNY SZÁMBAVÉTELÉRE
}

A Bizottság tagjaihoz eljuttatott, majd a 2001. öszi ülésen megvitatott elöterjesztés alapján, illetve az MTA Közgazdaságtudományi és Földrajztudományi Bizottsága által elkészített habitus vizsgálati szempontok alapján, a következö ajánlást állítottuk össze az MTA Regionális Tudományos Bizottsághoz benyújtott, akadémia doktori címhez szükséges habitus vizsgálat összeállításához.

A pályázó tudományos munkájának bemutatása

A pályázó által kiválasztott 5-7 tudományos publikáció benyújtása, amelyek új tudományos eredményeket mutatnak, egyben jellemzik a pályázó eddigi munkásságát. A tudományos eredmények összefoglalása - legfeljebb 10 oldal terjedelemben -, utalva a publikációs jegyzékben megadott múvekre. Ki kell térni az újszerü eredményekre, mind elméleti, mind módszertani, mind pedig alkalmazási módokban, gyakorlati hasznosításban. A kutatási eredmények mellett az oktatási, képzési tevékenységet, illetve a szakmai szervezỏmunkát is értékelni szükséges.

\section{Publikációs tevékenység}

A publikációs listát az 1 . mellékletben közölt összeállításban, időbeli sorrendben szükséges megadni. Minimum feltételnek számít egy tudományos monográfia vagy kettö (egy vagy több) társzerzövel írt tudományos könyv. (Monográfiának, vagy önállóan írt tudományos münek azt a kiadó által nyomtatásban megjelent és a széles szakmai közönséghez eljutott, nagy terjedelmü [min. 7 ív] mủvet tekintjük, amely a tudományterület egészét, vagy egy részét mind elméleti, mind módszertani, mind alkalmazási vonatkozásban feldolgozza, azokhoz új megállapításokat nyújt, s ezzel elösegíti a tudományterület fejlődését, vagy eredményeinek megismerését.) A publikációkban, a nemzetközi folyóiratokban közölt, lektorált dolgozatok mellett a hazai, a tudományterület által elfogadott folyóiratok tekinthetök meghatározónak, adott pontszám szerinti besorolással (2. melléklet), de lehetóség kínálkozik a pontrendszer alapján a publikációs tevékenység konvertálására.

A publikációkkal elérendó minimális pontszám 140, ebböl minimálisan 50 pont a külföldön megjelentek.

\section{Hivatkozások}

A hivatkozások jegyzékét mellékelni kell a pályázathoz, az adott cikk, illetve a hivatkozás helyének pontos megjelölésével. Az idegen nyelven (az idegen nyelven közölt cikkekben és tanulmányokban történt hivatkozásokat értjük ez alatt, vagyis beszámítható a Magyarországon megjelent, de idegen nyelven irtak is) történt hivatkozások száma minimálisan 10 egység legyen. 
A hivatkozásokkal elérendỏ minimális pontszám 60 , ebböl minimálisan 20 pont idegen nyelven.

\section{Kutatási témák}

Külön ki kell térni azokra a kutatási témákra, amelyekkel a pályázó foglalkozott az életmủ során, de döntően a beadást megelöző hét évben. Bemutatni a hazai országos, a nemzetközi projekteket, mindezeken belül a témavezetést, vagy alprogramok irányítását, a témák kidolgozása során elért eredményeket kell.

Az elérhetö maximális pontszám: 30.

\section{Tudományos továbbképzés}

A tudományos továbbképzésben való részvétel értékelésre kerül a habitus vizsgálat során, így a doktori képzésben való folyamatos (legalább 5 év) végzett oktatói, programvezetôi tevékenység, tudományos minősítésben való részvétel (opponencia, konzulensi feladatok), a pályázó irányítása alatt készült sikeres doktori disszertációk, országos tudományos diákkörön nyert dolgozatok száma, illetve más szakmai témavezetés (pl. Bólyai-ösztöndíj stb.).

Az elérhetỏ maximális pontszám: 30 .

\section{Tudományos közéleti tevékenység}

Jelentős országos és/vagy nemzetközi tudományos szervezetekben betöltött vezetői tisztség, választott tagság (akadémiai jellegủ tudományos társaságok esetében), valamint tudományos folyóiratok szerkesztőbizottságában való tagság, szerkesztői feladatok ellátása.

Az elérhető maximális pontszám: 30.

\section{A pontrendszer és a pontozási eljárás}

A fenti szempontok alapján az RTB Doktori Testülete pontszámokkal értékeli a pályázót az 1. mellékletben megadott mértékek és elöírt (jelzett minimális és maximális) értékek alapján. A tól-ig értékek esetében (5. kritérium) az egyes funkciók eltérö értékelését jelenítik meg.

A Doktori Testület 340 pontban határozza meg azt a küszöbértéket, amelyet a pályázónak el kell érnie ahhoz, hogy az érdemi vizsgálat elkezdődjön.

Az érdemi és komplex habitus vizsgálat, amit a Doktori Testület két tagja és maga a Testület végez, természetesen nem helyettesíti a pontrendszert, ám segítséget nyújt a pályázóknak a tudományos teljesítményük számbevételéhez, eddigi szakmai müködésük összevont értékeléséhez.

A habitus vizsgálat fenti szempontjai 2003. január 1-jétől a Bizottsághoz benyújtott pályázatokra érvényesek.

Győr, 2002. február 28. 
Tér és Társadalom 17. évf. 2003/1. 221-225. p.

\begin{tabular}{|c|c|c|}
\hline \multicolumn{3}{|c|}{$\begin{array}{l}\text { 1. MELLÉKLET } \\
\text { A Regionális Tudományos Bizottság } \\
\text { által folytatott habitus vizsgálat figyelembe vehetö tudományos teljesítményei, } \\
\text { s azok értékelési rendszere }\end{array}$} \\
\hline Témakör & Tartalom & Pontszám \\
\hline $\begin{array}{l}\text { 1. Publikációk, } \\
\text { hivatkozások }\end{array}$ & $\begin{array}{l}\text { Alapvető hazai szakmai folyóiratban megjelent } \\
\text { cikk, vagy tanulmány (lásd } 2 \text {. melléklet) }\end{array}$ & 5 \\
\hline \multirow{5}{*}{$\begin{array}{l}\text { A) Cikkek, ta- } \\
\text { nulmányok } \\
\text { Minimum: } 120 \\
\text { pont, ebböl } 50 \\
\text { pont külföldi } \\
\text { tanulmányokból }\end{array}$} & $\begin{array}{l}\text { Értékelhetö hazai szakmai folyóiratban megjelent } \\
\text { tanulmány, rendszeresen megjelenő konferencia- } \\
\text { kötetben közölt tanulmány (lásd 2. melléklet) }\end{array}$ & 4 \\
\hline & $\begin{array}{l}\text { Eseti hazai folyóiratban megjelent cikk, tanulmány, } \\
\text { illetve nem rendszeresen megjelenő konferencia- } \\
\text { kötetben közölt tanulmány (lásd 2. melléklet) }\end{array}$ & 2 \\
\hline & $\begin{array}{l}\text { Szemlecikk, könyvismertetés, } \\
\text { tudományos népszerüsítő cikk }\end{array}$ & 1 \\
\hline & $\begin{array}{l}\text { Idegen nyelven megjelent cikk, nemzetközi } \\
\text { szerkesztőbizottsággal rendelkező, lektorált, } \\
\text { szakmai szempontból elismert folyóiratban }\end{array}$ & 20 \\
\hline & $\begin{array}{l}\text { Szerkesztöbizottsággal rendelkező, lektorált, ismert } \\
\text { külföldi folyóiratban megjelent cikk, tanulmány }\end{array}$ & 10 \\
\hline \multirow{8}{*}{$\begin{array}{l}\text { B) Monográfiák, } \\
\text { könyvek } \\
\text { Minimum: } 60 \\
\text { pont és legalább } \\
\text { egy önálló vagy } \\
\text { két társszerzős } \\
\text { monográfia }\end{array}$} & Magyar nyelven írt könyv (társszerzővel) & $30(15)$ \\
\hline & Idegen nyelven írt könyv (társszerzövel) & $50(25)$ \\
\hline & Magyar nyelven írt könyv fejezete & $5 /$ fejezet \\
\hline & Idegen nye & $8 /$ fejezet \\
\hline & $\begin{array}{r}\text { Magyar nyelvú könyvs } \\
\text { (társszerkesztő }\end{array}$ & $10(5)$ \\
\hline & Idegen nyelvü könyvszerkesztés (társszerkes & $15(8)$ \\
\hline & Önálló tankönyv, jegyzet & 10 \\
\hline & Tankönyv, jegyzetrészlet & $3 /$ fejezet \\
\hline \multirow{2}{*}{$\begin{array}{l}\text { 2. Hivatkozások } \\
\text { Minimum: } 60 \text { pont }\end{array}$} & Idegen nyelven & 2 \\
\hline & Magyar nyelven & 1 \\
\hline \multirow{3}{*}{$\begin{array}{l}\text { 3. Kutatási } \\
\text { projektek } \\
\text { Maximum: } 30 \\
\text { pont }\end{array}$} & Magyar, országos támogatású pályázat, témavezető & 7 \\
\hline & $\begin{array}{c}\begin{array}{c}\text { Nemzetközi kutatási pályázat irányítása, } \\
\text { (alprogramvezetés) }\end{array} \\
\end{array}$ & $15(9)$ \\
\hline & Nem publikált, dokumentált kutatás témavezetése & 3 \\
\hline \multirow{4}{*}{$\begin{array}{l}\text { 4. Tudományos } \\
\text { továbbképzés } \\
\text { Maximum: } 30 \\
\text { pont }\end{array}$} & Doktori iskola oktatója & 3/program \\
\hline & Doktori iskolában témavezetés & 2/hallgató \\
\hline & Védett PhD témavezetője & 7/védés \\
\hline & $\begin{array}{l}\text { Más tudományos tevékenység, pl. konferenciák } \\
\text { szervezése, TDK, oktatási program kidolgozása }\end{array}$ & 2 \\
\hline \multirow{2}{*}{$\begin{array}{l}\text { 5. Tudományos } \\
\text { közéleti } \\
\text { tevékenység } \\
\text { Maximum: } 20 \\
\text { pont }\end{array}$} & $\begin{array}{c}\text { Országos vagy nemzetközi tudományos társaságban } \\
\text { való tagság, vezetö funkció }\end{array}$ & $0-20$ \\
\hline & $\begin{array}{c}\text { Szakmai folyóirat szerkesztỏbizottsági tagság, } \\
\text { szerkesztés }\end{array}$ & $0-10$ \\
\hline
\end{tabular}


Tér és Társadalom 17. évf. 2003/1. 221-225. p.

\section{MELLÉKLET}

A folyóiratok minösitése a regionális tudománnyal foglalkozó cikkek közlése alapján

\begin{tabular}{|c|c|c|c|c|}
\hline \multirow[b]{2}{*}{ Folyóirat neve } & \multicolumn{4}{|c|}{ Minősítése } \\
\hline & Alapvetö & Értékelhetö & Eseti, alkalmi & Nem releváns \\
\hline Acta Oeconomica & $\mathrm{xxx}$ & & & \\
\hline Alföld & & & & $x x x$ \\
\hline Alföldi Tanulmányok & $\mathrm{xxx}$ & & & \\
\hline Alföldi Társadalom & $\mathrm{xxx}$ & & & \\
\hline Aula & & $\mathrm{xxx}$ & & \\
\hline Bank Szemle & & & $\mathrm{xxx}$ & \\
\hline Comitatus & & $\mathrm{xxx}$ & & \\
\hline Demográfia & & $\mathrm{xxx}$ & & \\
\hline Educatio & & & $\mathrm{xxx}$ & \\
\hline Európai Tükör & & $\mathrm{xxx}$ & & \\
\hline Európai Szemle & & & $\mathrm{xxx}$ & \\
\hline A Falu & & & $\mathrm{xxx}$ & \\
\hline Falu, város, régió & & & & $\mathrm{xxx}$ \\
\hline Forrás & & & & $\mathrm{xxx}$ \\
\hline Földrajzi Értesítö & & $\mathrm{xxx}$ & & \\
\hline Földrajzi Közlemények & $\mathrm{xxx}$ & & & \\
\hline Gazdálkodás & & $\mathrm{xxx}$ & & \\
\hline Ipari Szemle & & $\mathrm{xxx}$ & & \\
\hline $\begin{array}{l}\text { INFO Társadalomtudo- } \\
\text { mány }\end{array}$ & $\mathrm{xxx}$ & & & \\
\hline Jelenkor & & & & $x x x$ \\
\hline Jogtudományi Közlöny & $\mathrm{xxx}$ & & & \\
\hline Közgazdasági Szemle & $\mathrm{xxx}$ & & & \\
\hline Külgazdaság & & $\mathrm{xxx}$ & & \\
\hline Limes & & & & $\mathrm{xxx}$ \\
\hline Magyar Jog & & $\mathrm{xxx}$ & & \\
\hline Magyar Közigazgatás & & $\mathrm{xxx}$ & & \\
\hline Magyar Tudomány & $\mathrm{xxx}$ & & & \\
\hline Marketing Menedzsment & & & $\mathrm{xxx}$ & \\
\hline Múhely & & & & $\mathrm{xxx}$ \\
\hline $\mathrm{OKO}$ & & & $\mathrm{xxx}$ & \\
\hline Pénzügyi Szemle & & $\mathrm{xxx}$ & & \\
\hline Politikatudományi Szemle & $\mathrm{XxX}$ & & & \\
\hline
\end{tabular}


Tér és Társadalom 17. évf. 2003/1. 221-225. p.

\begin{tabular}{|l|c|c|c|c|}
\hline \multirow{2}{*}{ Folyóirat neve } & \multicolumn{3}{c|}{ Minösítése } \\
\cline { 2 - 5 } & Alapvető & Értékelhető & Eseti, alkalmi & Nem releváns \\
\hline Pro Minoritate & & & $\mathrm{xxx}$ & \\
\hline Régió & & & $\mathrm{xxx}$ & \\
\hline Replika & & & & \\
\hline Statisztikai Szemle & $\mathrm{xxx}$ & & & \\
\hline Szociológiai Szemle & $\mathrm{xxx}$ & & & \\
\hline Társadalomkutatás & $\mathrm{xxx}$ & & & \\
\hline Tér és Társadalom & $\mathrm{xxx}$ & & & \\
\hline Területi Statisztika & $\mathrm{xxx}$ & & & \\
\hline Tiszatáj & & & & \\
\hline Történelmi Szemle & $\mathrm{xxx}$ & & & \\
\hline Valóság & & $\mathrm{xxx}$ & & \\
\hline Vezetéstudomány & & $\mathrm{xxx}$ & & $\mathrm{xxx}$ \\
\hline Vasi Szemle & & & & \\
\hline Borsodi Szemle & & & & \\
\hline Európa 2002 & & & & \\
\hline
\end{tabular}

Magyarázat:

- alapvetönek az a folyóirat tekinthető, amely rendszeresen a) közreadja a regionális tudomány eredményeit, b) a hazai tudomány egészére, vagy a társadalomtudományra vonatkozóan ismert, magasra értékelt, lektorált (5 pont),

- értékelhetőnek az a folyóirat tekinthető, amely időközönként, alkalmanként közread regionális tudományi cikkeket, a társtudományokban elismert és elfogadott, lektorált (4 pont),

- eseti az a folyóirat, amely estenként helyet ad a regionális tudománnyal foglalkozó cikkeknek, más szakmában elfogadott, ismert, nem lektorált (2 pont),

- nem relevánsnak tekinthetô az a folyóirat, ahol ritkán jelennek meg regionális tudományhoz tartozó szakcikkek, de a kiadványok népszerüek, elfogadottak (1 pont). 